\title{
Pengaruh Lama Perendaman dalam Berbagai Konsentrasi Giberelin (GA $)$ terhadap Perkecambahan Benih Kelapa Sawit (Elaeis guineensis Jacq.)
}

\author{
Effect of Immersion Time in Various Concentrations Gibberellins (GA3) on Oil Palm Seed Germination \\ (Elaeis guineensis Jacq.)
}

\author{
Agustiansyah $^{1 *}$, Ardian $^{2}$, Kukuh Setiawan $^{1}$, dan Devi Rosmala ${ }^{2}$ \\ ${ }^{1}$ Jurusan Agronomi dan Hortikultura, Fakultas Pertanian Universitas Lampung \\ ${ }^{2}$ Jurusan Agroteknologi, Fakultas Pertanian Universitas Lampung \\ *Email korespondensi: agustiansyah.1972@fp.unila.ac.id
}

Diterima: 18 Mei 2020 / Disetujui: 23 Juni 2020

\begin{abstract}
Palm oil seeds had physical dormancy in the germination process, Efforts to break dormancy of oil palm seeds were by immersion techniques in gibberellin plant growth regulators, The aims of research to determine the effect of immersion duration in various concentrations of gibberellins on oil palm seed germination, This research was conducted at the Seed and Plant Breeding Laboratory of the Faculty of Agriculture, University of Lampung, from February-June 2019, The treatments were arranged in a factorial design that immersion time of 1,3, 5, 7, and 9 days and gibberellin concentration 0, 100, 200, and 300 ppm, Based on the research concluded that immersion of oil palm seeds in gibberellin solution could increase the percentage of germination, maximum growth potential, speed of growth, and emergence of sprouts, The combination of immersion time and gibberellin concentration $(9$ days $+100 \mathrm{ppm})$ produced the highest germination rate $(57.5 \% \pm 11.0)$, maximum growth potential $(62.5 \% \pm 10.3)$, seed growth rate $(10.3 \%$ / etmal), Immersion could accelerate the emergence of sprouts (4th day after germination) each by 4.4\%, 4.4\%,8.9\%, and 6.7\% at the concentration of gibberellins 0, 100, 200, and $300 \mathrm{ppm}$,
\end{abstract}

Keywords: dormancy, gibberellins, palm oil

\section{ABSTRAK}

Benih kelapa sawit mengalami dormansi fisik dalam proses perkecambahannya, Upaya yang dilakukan untuk mengatasi dormansi pada benih kelapa sawit yaitu dengan teknik perendaman dalam zat pengatur tumbuh tanaman giberelin, Penelitian ini bertujuan untuk mengetahui pengaruh lama perendaman dalam berbagai konsentrasi giberelin terhadap perkecambahan benih kelapa sawit, Penelitian ini dilaksanakan di Laboratorium Benih dan Pemuliaan Tanaman Fakultas Pertanian Universitas Lampung dari bulan Februari-Juni 2019, Perlakuan disusun dalam rancangan faktorial yaitu lama perendaman 1, 3, 5, 7, dan 9 hari dan konsentrasi giberelin 0, 100, 200,dan 300 ppm, Berdasarkan penelitian diperoleh kesimpulan bahwa secara umum perendaman benih kelapa sawit dalam larutan giberelin dapat meningkatkan persentase perkecambahan, potensi tumbuh maksimum, kecepatan tumbuh, dan waktu munculnya kecambah, Kombinasi lama perendaman dan konsentrasi giberelin (9 hari+100 ppm) menghasilkan daya berkecambah paling tinggi (57,5\% $\pm 11,0)$, potensi tumbuh maksimum (62,5\% $\pm 10,3)$, kecepatan tumbuh benih (10,3\%/etmal), Perendaman dapat mempercepat waktu munculnya kecambah (hari ke-4 setelah pengecambah) masing-masing sebesar 4,4\%; 4,4\%; 8,9\%, dan 6,7\% pada konsentrasi giberelin 0, 100, 200, dan 300 ppm.

Kata kunci: dormansi, giberelin, kelapa sawit

\section{LATAR BELAKANG}

Kelapa sawit (Elaeis guineensis Jacq.) merupakan salah satu dari famili arecaceae yang menghasilkan minyak untuk tujuan komersil. Sudrajat dan Fitriya (2015) mengungkapkan bahwa Indonesia adalah produsen utama minyak sawit di dunia. Menurut Direktorat Jenderal Perkebunan (2018), luas perkebunan kelapa sawit di Indonesia mencapai 14,67 juta hektar (angka perkiraan sampai tahun 2019).

Salah satu kendala dalam pengembangan komoditi kelapa sawit adalah ketersediaan benih yang lambat dan tidak seragam. Hal ini disebabkan proses perkecambahan benih kelapa sawit mengalami masa dormansi benih. Dormansi pada benih kelapa sawit disebabkan adanya penghalang berupa struktur germpore yaitu operculum yang menutupi embrio sehingga radikula dan plumula mengalami kesulitan untuk keluar dari cangkang benihnya (Chaerani, 1992: Martine et al., 2011, Green et al., 2013).

Pemanasan kering (dry heat treatment) adalah metode pematahan dormansi kelapa sawit yang telah lama digunakan (Periasamy, 2002; Martine et al., 2009), namun masih menghasilkan persentase dan keseragaman perkecambahan yang bervariasi (Fondom et al., 2010). Di Indonesia, Chaerani 
(1992) telah melaporkan metode pematahan dormansi benih kelapa sawit dengan pemanasan kering selama 60 hari pada suhu $39-40^{\circ} \mathrm{C}$. Oleh karena itu, selain menggunakan metode pemanasan kering, perkecambahan benih kelapa sawit dapat ditingkatkan dengan penggunaan zat pengatur tumbuh. Penggunaan zat pengatur tumbuh dapat menambah kadar hormon endogen sehingga dapat meningkatkan daya berkecambah benih. Norsazwan et al. (2016) dan Nuraini et al. (2016) melaporkan penggunaan giberelin $\left(\mathrm{GA}_{3}\right)$ sebagai bahan pemacu perkecambahan benih kelapa sawit, namun persentase yang masih rendah $(67,78 \%)$ dan waktu pengecambahan yang relatif lama (50 hari). Perlakuan perendaman dalam giberelin dilaporkan dapat meningkatkan perkecambahan pada benih purwoceng, (Rusmin et al., 2011), mucuna (Astari et al., 2014), loquat (Al-Hawezy, 2013), sirsak (Polhaupessy, 2014). Namun demikian perlu dipelajari juga penggunaan konsentrasi ZPT yang sesuai untuk pematahan dormansi benih mengingat konsentrasi yang dibutuhkan berbeda-beda untuk setiap jenis komoditi. Tujuan penelitian ini adalah untuk mengetahui pengaruh lama perendaman dan konsentrasi giberelin $\left(\mathrm{GA}_{3}\right)$ terhadap perkecambahan benih kelapa sawit.

\section{BAHAN DAN METODE}

Penelitian ini dilaksanakan di Laboratorium Benih dan Pemuliaan Tanaman, Fakultas Pertanian, Universitas Lampung, Lampung dari bulan Februari - Juni 2019. Perlakuan disusun secara faktorial dengan dua faktor. Faktor pertama adalah perbedaan lama perendaman dalam giberelin yang terdiri dari 5 taraf yaitu 1 hari, 3 hari, 5 hari, 7 hari dan 9 hari. Faktor kedua adalah perbedaan konsentrasi giberelin yang terdiri dari 4 taraf yaitu 0 ppm, 100 ppm, 200 ppm, dan 300 ppm, sehingga diperoleh 20 kombinasi perlakuan. Penelitian ini menggunakan Rancangan Acak Kelompok (RAK), pengelompokan berdasarkan hari pengamatan. Setiap perlakuan terdiri dari tiga ulangan, setiap satu satuan percobaan terdiri dari 5 butir benih yang dikecambahkan dengan metode UKDdp (uji kertas digulung didirikan dalam plastik) pada kertas koran putih polos (CD) berukuran $12 \mathrm{X}$ $20 \mathrm{~cm}$. Perbedaan antar kombinasi perlakuan diketahui dengan menggunakan standar deviasi.

Benih kelapa sawit varietas Dura yang telah masak fisiologis, dikupas untuk membuang bagian mesocarp (sabut). Selanjutnya benih direndam dalam air bersih selama tujuh hari. Setelah direndam benih dioven pada suhu $40^{\circ} \mathrm{C}$ selama 35 hari. Selanjutnya benih direndam dalam larutan giberelin sesuai dengan konsentrasi giberelin dan lama perendaman. Benih dikecambahkan dalam germinator dengan metode UKDdp (uji kertas digulung didirikan dalam plastik) pada kertas koran putih polos (CD) berukuran $12 \mathrm{X}$ $20 \mathrm{~cm}$.

\section{HASIL DAN PEMBAHASAN}

\section{Persentase berkecambah benih}

Berdasarkan hasil penelitian menunjukkan bahwa perlakuan kombinasi lama perendaman dan konsentrasi giberelin berpengaruh baik pada persentase daya berkecambah benih kelapa sawit. Perkecambahan benih meningkat sejalan dengan lamanya perendaman dalam giberelin. Persentase berkecambah benih setelah direndam dalam larutan giberelin 1, 3, 5, 7, 9 hari masing-masing adalah $45,0 \% \pm 7,3 ; 45,0 \% \pm 7,3 ; 51,4 \% \pm 5,9 ; 45,7 \pm 10,4 ; 57,5 \% \pm 11,0$ pada masing-masing konsentrasi giberelin 100, 300, 300, 200, 100 ppm. Kombinasi lama perendaman dan konsentrasi giberelin (9 hari+100 ppm) menghasilkan daya berkecambah paling tinggi dibandingkan dengan kombinasi perlakuan lainnya yaitu 57,5\% $\pm 11,0$ (Gambar 1).

\section{Potensi Tumbuh Maksimum}

Potensi Tumbuh Maksimum (PTM) benih adalah keseluruhan benih yang dapat berkecambah, baik normal maupun abnormal. Sama halnya dengan persentase daya berkecambah, PTM meningkat seiring dengan lamanya perendaman dan peningkatan konsentrasi giberelin. Nilai PTM (\%) setelah direndam dalam larutan giberelin 1, 3, 5, 7, 9 hari masing-masing adalah $47,0 \% \pm 8,4 ; 52,5 \% \pm 6,5$; $51,4 \% \pm 5,9 ; \quad 46,7 \% \pm \quad 4,7 ; \quad 62,5 \% \pm 10,3$ masing-masing konsentrasi 100, 100, 300, 0, 100 ppm. Potensi tumbuh maksimum benih pada kombinasi perlakuan lama perendaman dan konsentrasi giberelin (9 hari+100 ppm) menghasilkan PTM paling tinggi yaitu sebesar $62,5 \% \pm 10,3$ (Gambar 2).

\section{Kecepatan Tumbuh Benih}

Nilai kecepatan tumbuh benih (KCT) adalah nilai yang menunjukkan jumlah benih yang berkecambah dalam 24 jam setiap harinya selama periode pengamatan. Pada pengamatan variabel KCT benih pada kombinasi perlakuan lama perendaman dan konsentrasi $\mathrm{GA}_{3}$ (9 hari+100 ppm) kecepatan tumbuh benih paling tinggi dibandingkan dengan kombinasi perlakuan lainnya yaitu menghasilkan kecepatan tumbuh sebesar 10.3\%/etmal (Gambar 3). Nilai KCT (\%/etmal [24jam]) tertinggi setelah direndam dalam larutan giberelin $1,3,5,7,9$ hari masing-masing adalah $6,8 \% \pm 1,5$; $8,7 \% \pm 1,3 ; \quad 9,4 \% \pm 1,7 ; \quad 8,2 \% \pm 2,0 ; \quad 10,3 \% \pm 1,8$ dan pada masing-masing konsentrasi 100, 300, 200, 220, dan 100 ppm. (Gambar 3).

\section{Waktu Munculnya Kecambah}

Berdasarkan hasil pengamatan menunjukkan bahwa perlakuan perendaman selama 9 hari mempercepat waktu munculnya kecambah (hari ke-4 setelah pengecambahan), baik yang direndam dengan giberelin maupun tanpa perendaman dalam giberelin yaitu masing-masing sebesar $4,4 \% ; 4,4 \%, 8,9 \%$, dan $6,7 \%$ pada konsentrasi giberelin 0 , 100, 200, dan 300 ppm. Benih mulai muncul secara serempak pada perlakuan lainnya pada hari ke-7 pengamatan kecuali pada perendaman 1 hari, radikula baru mulai muncul pada hari pengamatan hari ke-14. Munculnya kecambah mencapai puncak pada hari pengamatan ke-35 hari dan selanjutnya stabil sampai pengamatan hari ke-42 (Tabel 1). 


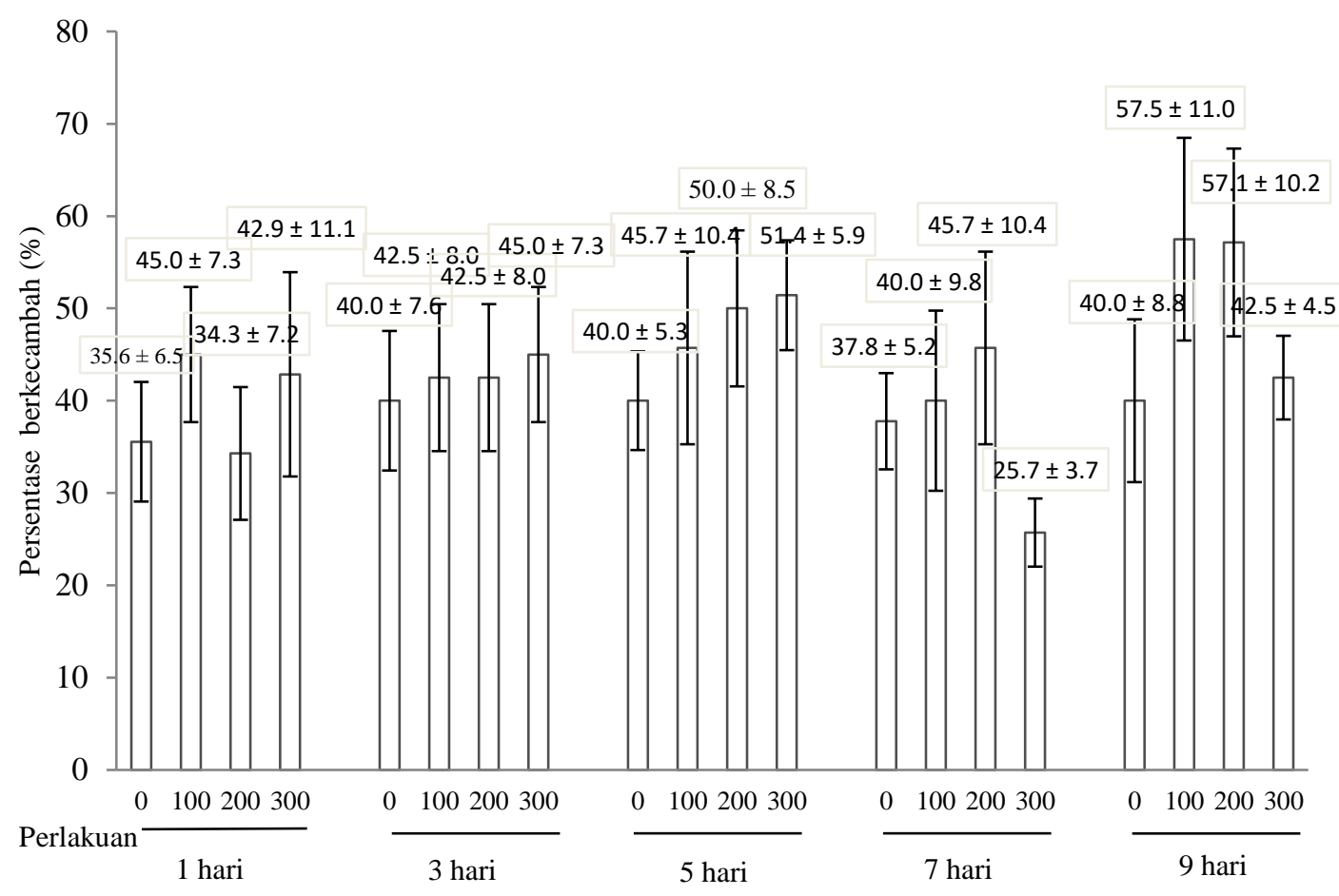

Gambar 1. Pengaruh lama perendaman dalam konsentrasi giberelin terhadap persentase berkecambah benih.

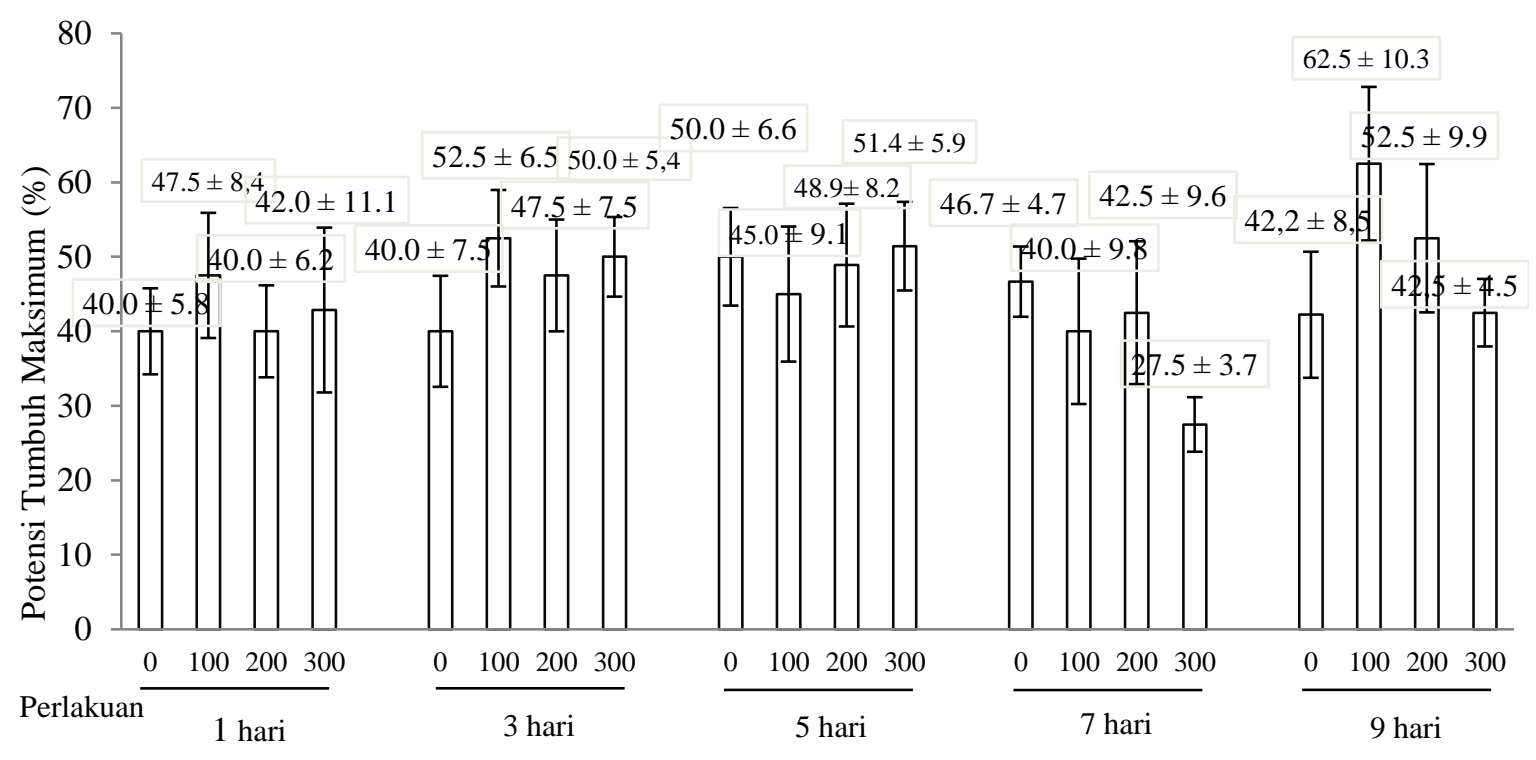

Keterangan: 0, 100, 200, 300 konsentrai Giberelin dalam ppm; 1, 3, 5, 7, 9 lama perendaman (hari))

Gambar 2. Pengaruh lama perendaman dalam konsentrasi giberelin terhadap potensi tumbuh maksimum benih. 


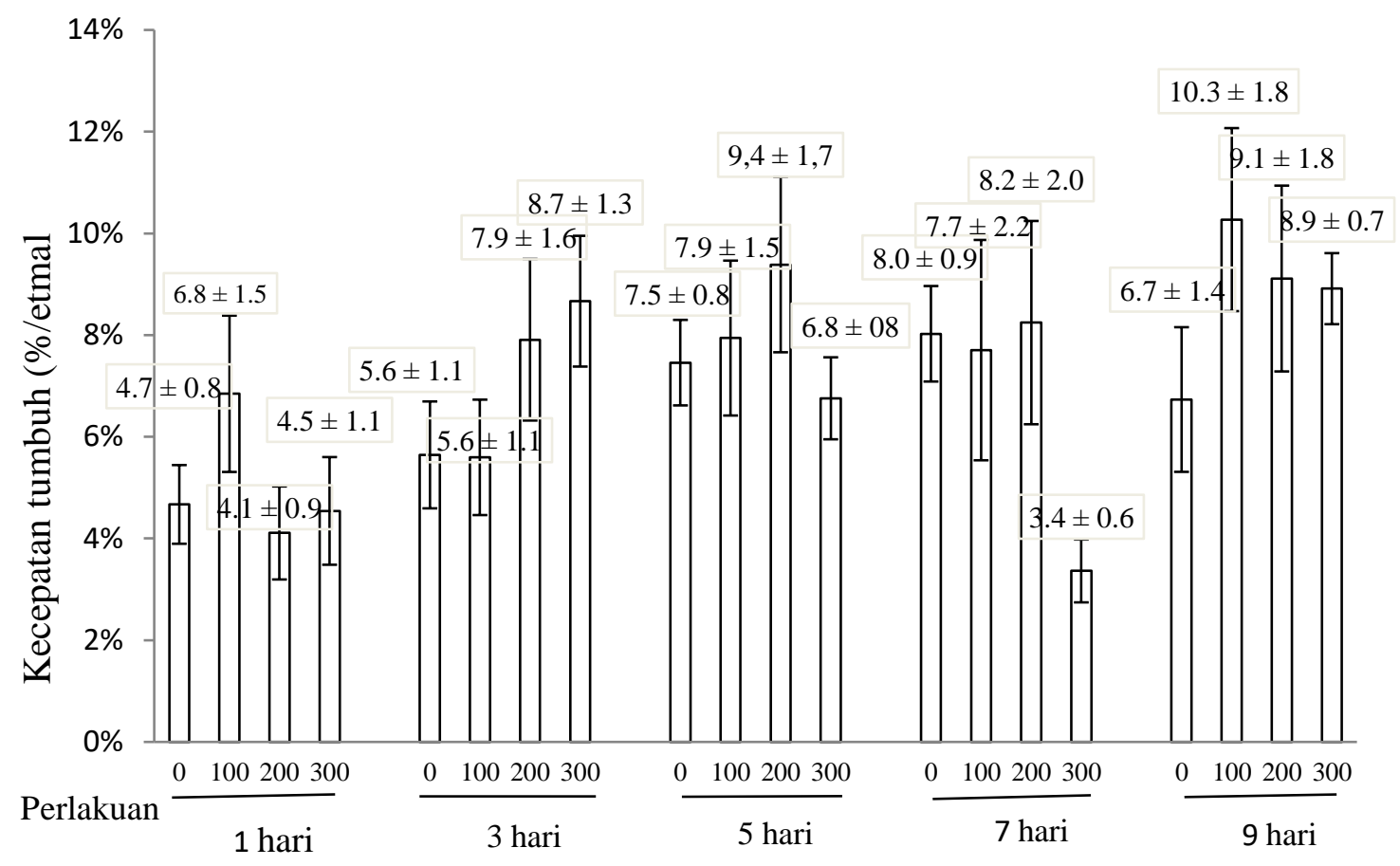

Keterangan: 0, 100, 200, 300 konsentrai Giberelin dalam ppm; 1, 3, 5, 7, 9 lamaperendaman (hari).

Gambar 3. Pengaruh lama perendaman dalam konsentrasi giberelin terhadap potensi tumbuh maksimum benih

Tabel 1. Persentase munculnya kecambah setelah direndam dalam berbagai konsentrasi giberelin.

\begin{tabular}{lcccccc}
\hline Perlakuan & \multicolumn{5}{c}{ Waktu munculnya kecambah hari ke- (\%) } \\
\cline { 2 - 6 } & 4 & 7 & 21 & 28 & 35 & 42 \\
\hline 1 hari perendaman $+0 \mathrm{ppm}$ & 0,0 & 0,0 & 24,4 & 37,8 & 37,8 & 40,0 \\
1 hari perendaman $+100 \mathrm{ppm}$ & 0,0 & 0,0 & 31,1 & 40,0 & 41,1 & 42,2 \\
1 hari perendaman $+200 \mathrm{ppm}$ & 0,0 & 0,0 & 13,3 & 22,2 & 25,6 & 26,7 \\
1 hari perendaman $+330 \mathrm{ppm}$ & 0,0 & 0,0 & 15,6 & 22,2 & 24,4 & 26,7 \\
3 hari perendaman $+0 \mathrm{ppm}$ & 0,0 & 6,7 & 20,0 & 33,3 & 35,6 & 37,8 \\
3 hari perendaman $+100 \mathrm{ppm}$ & 0,0 & 6,7 & 20,0 & 37,8 & 40,0 & 40,0 \\
3 hari perendaman $+200 \mathrm{ppm}$ & 0,0 & 8,9 & 26,7 & 40,0 & 42,2 & 42,2 \\
3 hari perendaman $+300 \mathrm{ppm}$ & 0,0 & 11,1 & 26,7 & 42,2 & 44,4 & 44,4 \\
5 hari perendaman $+0 \mathrm{ppm}$ & 0,0 & 8,9 & 26,7 & 35,6 & 40,0 & 40,0 \\
5 hari perendaman $+100 \mathrm{ppm}$ & 0,0 & 8,9 & 33,3 & 37,8 & 37,8 & 40,0 \\
5 hari perendaman $+200 \mathrm{ppm}$ & 0,0 & 13,3 & 37,8 & 46,7 & 48,9 & 48,9 \\
5 hari perendaman $+300 \mathrm{ppm}$ & 0,0 & 6,7 & 17,8 & 26,7 & 35,6 & 35,6 \\
7 hari perendaman $+0 \mathrm{ppm}$ & 0,0 & 20,0 & 33,3 & 42,2 & 42,2 & 42,2 \\
7 hari perendaman $+100 \mathrm{ppm}$ & 0,0 & 15,6 & 26,7 & 28,9 & 31,1 & 33,3 \\
7 hari perendaman $+200 \mathrm{ppm}$ & 0,0 & 13,3 & 28,9 & 35,6 & 37,8 & 37,8 \\
7 hari perendaman $+300 \mathrm{ppm}$ & 0,0 & 4,4 & 8,9 & 17,8 & 22,2 & 22,2 \\
9 hari perendaman $+0 \mathrm{ppm}$ & 4,4 & 15,6 & 20,0 & 31,1 & 37,8 & 37,8 \\
9 hari perendaman $+100 \mathrm{ppm}$ & 4,4 & 11,1 & 24,4 & 42,2 & 48,9 & 48,9 \\
9 hari perendaman $+200 \mathrm{ppm}$ & 8,9 & 11,1 & 26,7 & 42,2 & 46,7 & 46,7 \\
9 hari perendaman $+300 \mathrm{ppm}$ & 6,7 & 15,6 & 26,7 & 37,8 & 37,8 & 37,8 \\
\hline
\end{tabular}


Berdasarkan hasil penelitian, lama perendaman dan pemberian giberelin dapat meningkatkan persentase perkecambahan, potensi tumbuh maksimum, kecepatan tumbuh, dan waktu munculnya kecambah (Gambar 1, 2, 3, dan Tabel 1). Pada penelitian ini giberelin masuk kedalam benih melalui germpore yang operculumnya telah retak akibat pemanasan sebelumnya. Setelah imbibisi terjadi proses perkecambahan meningkat karena kehadiran air dan giberelin. Menurut (Copeland dan McDonald, 2005; Widajati et al. 2012), giberelin merangsang sintesis enzim-enzim yang berhubungan dengan hidrolisis seperti $\alpha$ - amilase. Enzim $\alpha$ - amilase inilah yang akan merombak karbohidrat menghasilkan energi (ATP) untuk perkecambahan. Nuraeni et al. (2016) melaporkan peningkatkan perkecambahan benih kelapa sawit pada perlakuan giberelin 100 dan 200 ppm. Farhana et al,(2013) melaporkan penggunaan etephon pada pematahan dormansi benih kelapa sawit.

Lama perendaman dalam giberelin dapat meningkatkan persentase perkecambahan, potensi tumbuh maksimum, kecepatan tumbuh, dan waktu munculnya kecambah. Perendaman sembilan hari menghasilkan pengamatan tertinggi untuk persentase berkecambah yaitu $57 \pm 11,0, \pm 11,0$, potensi tumbuh maksimum $62,5 \% \pm 10,3$, kecepatan tumbuh 9,4 $\pm 1,7 \%$ /etmal [24jam]), dan waktu munculnya kecambah pada hari ke-4 pengamatan perkecambahan yaitu $8,9 \%$ benih berkecambah. Semakin lama benih direndam menyebabkan akumulasi giberelin meningkat. Hasil uji laboratorium menunjukkan bahwa kandungan giberelin pada benih kelapa sawit yang dipanaskan selama 35 hari pada suhu $40{ }^{\circ} \mathrm{C}$ sebesar $25,52 \mathrm{ppm}$. Kandungan tersebut jauh dibawah rata-rata kebutuhan benih yang mengalami dormansi untuk berkecambah. Agustin dan Aprilinati (2011) menyimpulkan perendaman benih Verschaffeltia splendida H.A. Wendl dalam giberelin 1500 ppm pada suhu ruang dapat meningkatkan persentase benih berkecambah, kecepatan perkecambahan, dan panajang tunas. Asra (2014) melaporkan pada benih konsentrasi GA3 dan lama perendaman memperlihatkan pengaruh yang nyata terhadap persentase perkecambahan dan vigoritas Calopogonium caeruleum.Perlakuan yang terbaik dalam menghasilkan persentase perkecambahan Calopogonium caeruleum tertinggi adalah giberelin 500 ppm dengan lama perendaman 24 jam. Normaya et al. (2015) melaporkan pada benih tembesu (Fragraea fragrans Roxb.) perendaman berbagai konsentrasi giberelin mampu meningkatkan perkecambahan biji tembesu. Konsentrasi giberelin terbaik untuk perkecambahan biji tembesu adalah $125 \mathrm{ppm}$.

\section{KESIMPULAN}

Berdasarkan penelitian diperoleh kesimpulan bahwa secara umum perendaman benih kelapa sawit dalam larutan giberelin dapat meningkatkan persentase perkecambahan, potensi tumbuh maksimum, kecepatan tumbuh, dan waktu munculnya kecambah. Kombinasi lama perendaman dan konsentrasi giberelin (9 hari+100 ppm) menghasilkan daya berkecambah paling tinggi $(57,5 \% \pm 11,0)$, potensi tumbuh maksimum $(62,5 \% \pm 10,3)$, kecepatan tumbuh benih (10,3\%/etmal). Perendaman dapat mempercepat waktu munculnya kecambah (hari ke4 setelah pengecambahan) masing-masing sebesar $4,4 \%$, $4,4 \%, 8,9 \%$, dan $6,7 \%$ pada konsentrasi giberelin 0,100 , 200, dan 300 ppm.

\section{DAFTAR PUSTAKA}

Agustin, E. K., \& Aprilianti, P. (2011). Pengaruh pemakaian hormon tumbuh GA3 (giberelin acid) terhadap perkecambahan dan pertumbuhan biji Verschaffeltia splendida H.A. Wendl. Berk, Penel, Hayati Edisi Khusus, 7A, (157-160).

Al-Hawezy, S. M. N. (2013). The role of the different concentrations of GA3 on seed germinaton and seedling growth of loquat (Eriobotrya japonica L.). Journal of Agriculture and Veterinary Science, 4(5), 1-6.

Asra, R. (2014). Pengaruh hormon giberelin (GA3) terhadap daya kecambah dan vigoritas Calopogonium caeruleum, Biospecies. (7)1, 29-33.

Astari, R. P., Rosmayanti., \& Bayu, E. S. (2014). Pengaruh pematahan dormansi secara fisik dan kimia terhadap kemampuan berkecambah benih mucuna (Mucuna bracteata D.C). Jurnal Agroekoteknologi, 2(2), 803-812.

Chaerani, H. (1992). Kajian Kemunduran Viabilitas Benih kelapa sawit. Berita Penelitian Perkebunan, 2(3), 107-114.

Copeland, L. O., \& McDonald, M. B. (2005). Principles of seed science and sechnology. Chapman and Hall Press. New York. 409 p.

Direktorat Jenderal Perkebunan. (2018). Statistik Perkebunan Indonesia. Kelapa Sawit. Jakarta: Sekretariat Direktorat Jenderal Perkebunan.

Farhana, B., Ilyas, S., \& Budiman, F.L. 2013. Pematahan Dormansi Benih Kelapa Sawit (Elaeis guineensis Jacq.) dengan Perendaman dalam Air Panas dan Variasi Konsentrasi Ethephon. Bul, Agrohorti, 1(1), 72-78.

Fondom, N. Y. (2010). Breaking seed dormancy: revisiting heat-treatment duration ongermination and subsequent seedling growth of oil palm (Elaeis guineensis Jacq.) Progenies. Journal of Agricultural Science, 2(2), 101-110.

Green, M., Lima, W. F. A., de Figueiredo, A. F., Atroch, A. L., Lopes, R., da Cunha, R. N. V., \& Teixeira, 
P. C. (2013). Heat-Treatment and Germination of Oil Palm Seeds (Elaeis guineensis Jacq.). Journal of Seed Science, 35(3), 296-301.

Martine, B. M., Hilaire K. T., Mongomake, K., Roger K. K., Eugene, K. K., \& Justin, K.Y. (2011). Effect of the Hydrogen Peroxide Treatments on Germination of Oil Palm (Elaeis guineensis Jacq.) Seeds. International Journal of Agricultural and Food Science, 1(3), 58-65.

Normaya. D., Isda M. N., \& Fatonah, S. (2015). Respon perkecambahan biji tembesu (Fragraea fragrans roxb.) pada perendaman berbagai konsentrasi giberelin (GA3). Repository Universitas Riau.

Norsazwan, M. G., Puteh, A. B., \& Rafii, M. Y. (2016). oil palm (Elaeis quineensis Jack.) seed dormancy type and germination pattern. Seed Science and Technology, 44(1), 15-26.

Nuraini, A., Pangaribuan, I. F., \& Suherman, C. (2016). Pemecahan dormansi benih kelapa sawit dengan metode dry heat treatment dan pemberian giberelin. Agrin., 20(2), 99-106.
Periasamy, A., Gopapal, K., \& Soh, A. C. (2002). Productivity Improvements in Seed Processing Techniques for Commercial Oil Palm Seed Production. The Planter, 78, 429-442.

Polhaupessy, S. (2014). Pengaruh konsentrasi giberelin dan lama perendaman terhadap perkecambahan biji sirsak (Anonna muricata 1.). Biopendix, 1(1), 71-76.

Rusmin, D., Suwarno, F. C., \& Darwati, I. (2011). Pengaruh Pemberian GA3 pada Berbagai Konsentrasi dan Lama Imbibisi terhadap Peningkatan Viabilitas Benih Purwoceng (Pimpinella pruatjan Molk,). Jurnal Penelitian Tanaman Industri, 17(3), 89-94.

Sudrajat, \& Fitriya. (2015). Optimasi dosis pupuk dolomit pada tanaman kelapa sawit (Elaeis guineensis jacq.) Belum menghasilkan umur satu tahun. Agrovigor: Jurnal Agroekoteknologi. 8 (1), 1-8.

Widayati, E., Murniati, E., Palupi, E. R., Kartika, T., Suhartanto, M. R., \& Qadir, A. (2012). Dasar Ilmu dan Teknologi Benih. Departemen Agronomi dan Hortikultura IPB. Institut Pertanian Bogor. 